\title{
Rainfall driven and wild-bird mediated avian influenza virus outbreaks in Australian poultry
}

\author{
Marta Ferenczi ${ }^{1}$, Christa Beckmann ${ }^{1,2,3}$ and Marcel Klaassen ${ }^{1^{*}}$
}

\begin{abstract}
Globally, outbreaks of Avian Influenza Virus (AIV) in poultry continue to burden economies and endanger human, livestock and wildlife health. Wild waterbirds are often identified as possible sources for poultry infection. Therefore, it is important to understand the ecological and environmental factors that directly influence infection dynamics in wild birds, as these factors may thereby indirectly affect outbreaks in poultry. In Australia, where large parts of the country experience erratic rainfall patterns, intense rainfalls lead to wild waterfowl breeding events at temporary wetlands and increased proportions of immunologically naive juvenile birds. It is hypothesized that after breeding, when the temporary wetlands dry, increasing densities of immunologically naïve waterbirds returning to permanent water bodies might strongly contribute to AIV prevalence in wild waterfowl in Australia. Since rainfall has been implicated as an important environmental driver in AIV dynamics in wild waterbirds in southeast Australia and wild waterbirds are identified globally to have a role in virus spillover into poultry, we hypothesise that rainfall events have an indirect effect on AIV outbreaks in poultry in southeast Australia. In this study we investigated this hypothesis by examining the correlation between the timing of AIV outbreaks in poultry in and near the MurrayDarling basin in relation to temporal patterns in regional rainfall since 1970. Our findings support our hypothesis and suggest that the risk of AIV outbreaks in poultry increases after a period of high rainfall, with peak AIV risk two years after the onset of the high-rainfall period. This is presumably triggered by increased rates of waterbird breeding and consequent higher proportions of immunologically naïve juvenile waterbirds entering the population directly after major rainfall events, which subsequently aggregate near permanent water bodies when the landscape dries out.
\end{abstract}

Keywords: waterfowl, infection dynamics, climatic forcing, domestic chicken, domestic duck, Gallus gallus domesticus, Anas platyrhynchos domesticus, human-wildlife conflict

\section{Introduction}

High pathogenicity outbreaks of Avian Influenza Virus (AIV) in domestic poultry and the possibility of transmission of AIV to humans can result in extensive socioeconomic costs [1-3]. AIV in its low pathogenicity form (typically causing only mild or non-detectable clinical

\footnotetext{
* Correspondence: marcel.klaassen@deakin.edu.au

${ }^{1}$ Centre for Integrative Ecology, School of Life \& Environmental Sciences, Deakin University, 75 Pigdons Road, 3216 Geelong, VIC, Australia Full list of author information is available at the end of the article
}

signs in poultry; termed LPAI) occurs naturally in wild bird populations [4]. In recent years, research has focused on the wild-bird assisted dispersal of high pathogenicity forms (typically causing severe clinical signs and rapid death in gallinaceous poultry; termed HPAI) and notably AIV-H5-Clade-2.3.4.4, of which wave upon wave currently causes havoc in poultry industries across the globe e.g. [5, 6]. Another role for wild birds in the infection of poultry results from the occasional evolution of a HPAI in poultry after alleged exposure to LPAI from

(c) The Author(s). 2021 Open Access This article is licensed under a Creative Commons Attribution 4.0 International License, which permits use, sharing, adaptation, distribution and reproduction in any medium or format, as long as you give appropriate credit to the original author(s) and the source, provide a link to the Creative Commons licence, and indicate if changes were made. The images or other third party material in this article are included in the article's Creative Commons licence, unless indicated otherwise in a credit line to the material. If material is not included in the article's Creative Commons licence and your intended use is not permitted by statutory regulation or exceeds the permitted use, you will need to obtain permission directly from the copyright holder. To view a copy of this licence, visit http://creativecommons.org/licenses/by/4.0/ The Creative Commons Public Domain Dedication waiver (http://creativecommons.org/publicdomain/zero/1.0/) applies to the data made available in this article, unless otherwise stated in a credit line to the data. 
wild birds [7-9]. Virus spillover onto poultry farms could occur when infected wild birds enter or come close to poultry barns. These wild birds could either directly infect the chickens, ducks and other poultry species, or indirectly contaminate water and surfaces from where the virus is transmitted to the poultry, potentially assisted by farm workers, pets or transport of equipment $[10,11]$. Therefore, we can assume that the same ecological and environmental factors that foster epizootics of LPAI in wild birds would indirectly result in increased incidence of LPAI (and subsequently evolved HPAI) outbreaks in poultry.

Due to HPAI outbreaks in poultry there is great interest in the ecological and environmental factors that influence infection dynamics in wild birds and the possible virus transmissions between wild birds and poultry e.g. [12]. To date, the majority of research on AIV dynamics in wild birds has been conducted in ducks in the genus Anas, being the prime wild bird reservoir of AIV [13, 14], and in the northern hemisphere. The AIV pattern observed there is strongly seasonal, with a yearly peak in late summer/early autumn, followed by low prevalence in winter $[15,16]$. Across North America the intensity of these infection dynamics varies geographically in relation to the strength of the seasonal patterns which is thought to drive recruitment patterns [17]. Studies that included birds from the southern hemisphere showed that peaks of AIV prevalence in waterfowl communities are lower there than in the northern hemisphere [18]. Nonetheless, a shallow seasonal peak was suggested in southern hemisphere birds [19]. Furthermore, recent studies in temperate southeast Australia [18], where dabbling ducks are also identified as the primary AIV reservoir [20], showed that AIV prevalence was related to irregular, nonseasonal rainfall patterns.

Several ecological mechanisms have been studied as potential drivers of AIV dynamics in wild birds [16, 17, 19, 21]. Among wild waterbird communities, three ecological mechanisms have been suggested as the primary drivers of the seasonal AIV dynamics in the northern hemisphere: (i) the annual congregation of migratory birds at staging and wintering sites increases contact rates between individuals, and thereby infection rates [19], (ii) an increase in the abundance of immunologically naïve young birds results in a higher number of individuals susceptible to infection in the waterbird community $[16,22]$ and (iii) increases in energy-demanding activities, notably in relation to migration, potentially impairing immunocompetence $[21,23]$. In general, the ecological drivers for disease dynamics are importantly linked to seasonal variation in resources in the northern hemisphere [21, 24, 25]. Large parts of the globe, however, are far less seasonal [26].
In Australia, for instance, water availability is highly variable and an important factor in the ecology and stark variations in numbers of waterfowl [27-29]. Across much of the Australian continent, climatic conditions are extreme and non-seasonal [30]. Although regular rainfall occurs seasonally in the Australian tropics (summer) and the temperate southeast and southwest regions (winter-spring), water availability is largely non-seasonal across the rest of the continent [30, 31]. In southeastern Australia, inter-annual variation in rainfall is very high, with higher rainfall being positively related to waterfowl breeding [31]. Wet and dry periods can each persist for several years [31], occasionally creating extreme climate events, such as the 'Big Dry' phenomenon in southeastern Australia between 1997 and 2009 [32].

Globally, waterfowl numbers have been found to be tightly linked to water availability in the landscape e.g. [33] and it is thus unsurprising that these irregular rainfall patterns in Australia strongly influence the movement and breeding biology of many Australian waterfowl species. During wet periods, bird numbers increase at flooded areas where food sources become available, creating appropriate conditions for breeding [34, 35]. Afterwards, when flooded areas start to dry and reduce in size, waterbirds congregate on the remaining wetlands [36-38]. Klaassen et al. [39] suggested that the non-seasonal and often multi-year alternations of wet and dry periods that influence the breeding ecology of waterfowl might, in turn, affect the temporal pattern of AIV prevalence on the Australian continent. Applying the previously mentioned ecological drivers (i.e. i, ii, iii) to the climatic conditions in the southern hemisphere, Klaassen et al. [39] hypothesized that intense rainfall leads to breeding events and increased numbers of immunologically naïve juvenile birds. After breeding, when the temporary wetlands dry, increasing densities of immunologically naïve waterbirds returning to permanent water bodies might importantly influence AIV prevalence in wild waterfowl in Australia. In addition, the reduced food availability that accompanies the drying ephemeral wetlands can lead to reduction in birds' immunocompetence [40] and therefore further increase AIV infection risk. Ferenczi et al.'s [18] findings from temperate southeast Australia also support Klaassen et al.'s [39] hypothesis that irregular rainfall influences population dynamics and age structure within the duck community, which may subsequently affect AIV dynamics.

As (1) rainfall is an important environmental driver in AIV dynamics in wild Australian waterbirds [18] and (2) wild waterbirds, especially ducks, are identified globally to have a role in virus spillover into poultry [41-43] and (3) all HPAI poultry outbreaks in Australia can be traced back to an endemic Australian H7 lineage most likely 
spilled over from wild birds [44], we suggest that rainfall events have an indirect effect on AIV outbreaks in Australian poultry. We investigated this hypothesis by examining the correlation between the timing of AIV outbreaks in poultry in a region that contains most of Australia's poultry-dense areas and accounts for most of Australia's poultry production, the Murray-Darling basin and nearby locations, in relation to temporal patterns in regional rainfall.

\section{Materials and methods}

\section{Avian influenza virus outbreak data}

The Australian poultry industry is dominated by the production of chicken eggs and meat, $60 \%$ of which is produced within the Murray-Darling Basin. We tabulated the LPAI and HPAI outbreaks on poultry farms in Australia from the National Avian Influenza Surveillance Dossier [45], NSW Animal Health Surveillance Newsletters [46], Animal Health in Australia Annual Reports [47], World Animal Health Information Database (WAHID) Interface [48] and reports in the primary literature [49-51]. There is no systematic surveillance for AIV within the Australian poultry industry and the majority, if not all, LPAI and HPAI detections were made upon investigating clinical signs, which, albeit mild, often also arise upon infection with LPAI. However, detections of HPAI do trigger increased vigilance and the two novel infections of LPAI within Victoria, one month after a HPAI outbreak in this state, might have gone undetected if that HPAI outbreak had not occurred. We found that, with one exception in Tasmania and one in Western Australia [52], all the AIV outbreaks in poultry in Australia occurred in or in close proximity to the Murray-Darling basin (i.e. within $100 \mathrm{~km}$ of the basin's boundary). On a continental scale, the Murray Darling Basin is a highly significant waterbird area including as many as 18,500 interconnected wetlands of which 98 support more than 10,000 waterbirds each, notably ducks [53]. Also, from a poultry-production perspective the area is of continental significance, which is the prime rationale for this study to focus on this basin. In our analysis, we thus included all outbreaks in commercial poultry from the Murray-Darling basin and sites within $100 \mathrm{~km}$ of its boundary. Outbreaks and their timing of first occurrence (i.e. month and year) were defined as events with occurrence of severe (in case of HPAI) or mild (in case of LPAI) clinical signs. In cases where multiple farms were infected with the same strain only the initial outbreak was included to capture spillover from wild birds and not farm-to-farm transmission.

\section{Weather data and statistical analysis}

In order to investigate AIV outbreak events in relation to rainfall, we obtained monthly total rainfall data $(\mathrm{mm})$ averaged across the entire Murray-Darling basin from the Australian Bureau of Meteorology [54] between January 1970 until October 2020. The effects of weather are not always immediately expressed in ecological processes $[28,55]$, thus there may be a cumulative effect and/or a time lag between rainfall, waterfowl breeding events and associated changes in the epidemiology of AIV within wild bird populations and AIV outbreaks in poultry. Ecological meaningful rainfall variables that can potentially predict AIV outbreaks in poultry may thus vary in (1) the period over which rainfall is integrated (termed "rainfall period" from here on) and (2) the time lag between this rainfall period and the increased AIV prevalence after breeding that ultimately leads to an increased risk of AIV outbreaks in poultry (termed "time lag period" from here on). We tested 600 models using logistic regression in $\mathrm{R}$ [56], where for each month from January 1970 to October 2020 we used presence/absence of an outbreak as the response variable and total monthly rainfall as the explanatory variable. Each of the 600 models varied in how rainfall was calculated, with the rainfall period varying one to 24 months and the time lag period varying from zero to 24 months. For example, the rainfall category of two months "rainfall period" with zero "time lag period" means that total monthly rainfall was averaged over two months preceding a focal month. As another example, for a rainfall category of three months "rainfall period" with one month "time lag period" means that total monthly rainfall was averaged over the second, third and fourth month (i.e. skipping the first month) prior to the focal month. To appropriately weight incidentally co-occurring outbreaks (i.e. outbreaks happening within the same month of the same year; 3 occurrences), one of the outbreaks was moved to the following month. To select the best model(s) among the 600 tested, we used Akaike's Information Criterion (AIC) considering the top model to be the model with the lowest AIC but models within 2 AIC units also to have substantial support.

\section{Results}

We found eight HPAI and eight LPAI outbreaks linked to unique strains in commercial poultry across the Murray-Darling basin and close vicinity between 1976 and 2020 to analyse AIV outbreak events in relation to rainfall (Fig. 1; Table 1). For the 610 months over the period January 1970 to October 2020, 600 different rainfall indices were calculated varying in rainfall and timelag period. The best model with the lowest AIC (143.11) predicted that the likelihood of an outbreak would increase with increased rainfall (slope of the log odds 0.08 , $\mathrm{P}<0.002)$. The rainfall index for this top model was calculated over a period of 14 months and had a subsequent time-lag period of also 14 months. Thus, 


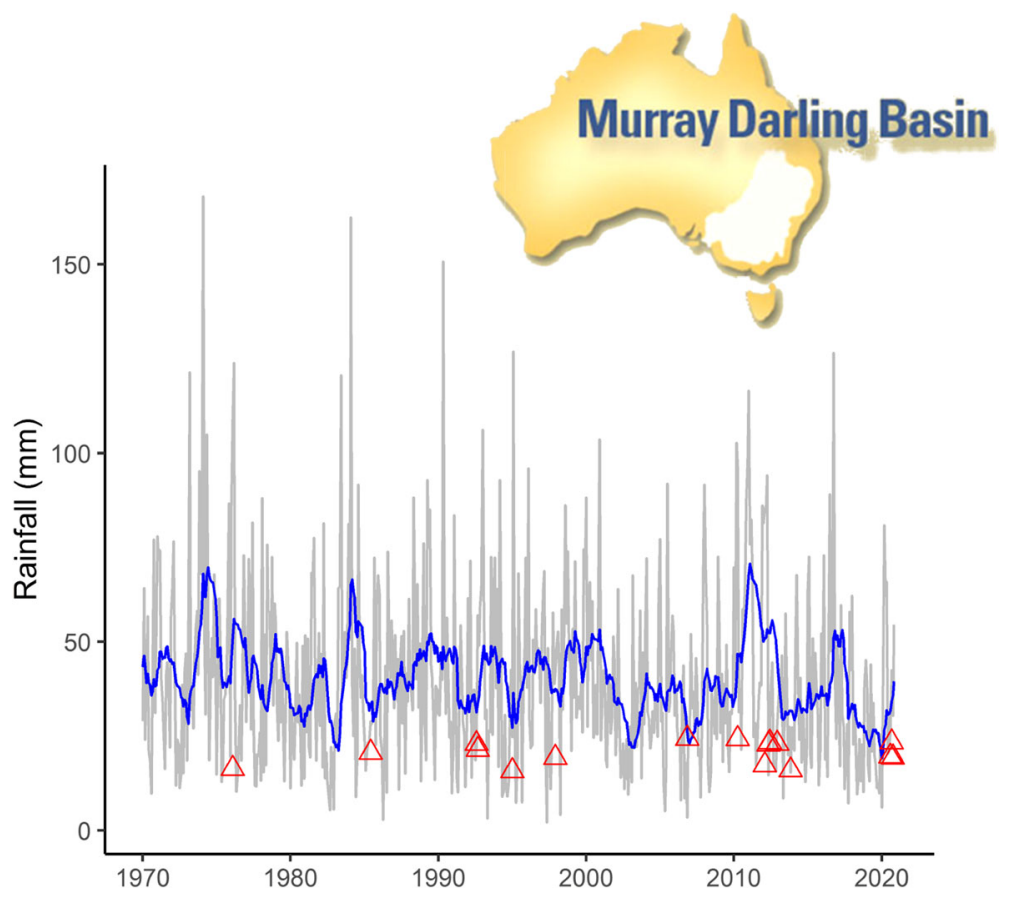

Fig. 1 Timeline of avian influenza outbreaks (red triangles) in commercial poultry in the Murray-Darling basin and close vicinity against mean monthly (grey line) and right-aligned rolling mean rainfall across the basin (blue line; i.e. indicating the mean rainfall in the preceding twelve-months)

according to this model, outbreaks tended to occur 28 months after the onset of a 14-month rainfall period. An overview of the estimated AICs and log odds slopes across all 600 tested models are depicted in Fig. 2. Another 25 models where within 2 AIC units of the top model, all with a positive slope of the log odds between 0.04 and 0,08 (in all cases $\mathrm{P}<0.007$ ) and should thus also be considered as good candidate models (Fig. 2). Fourteen of those had similar rainfall (11-16 months) and time-lag (12-15 months) periods to the best model. Ten had considerably shorter rainfall periods (5-9 months) but longer time-lag periods (19-23 months). Remarkably though, all 26 models tended to predict a higher chance of AIV outbreaks in poultry around 27 months after the onset of a particularly high rainfall period (i.e. the sum of rainfall and time-lag period has a median of 27 months and a range of 25-29 months and the top models thus all fall along a diagonal in both panels of Fig. 2).

\section{Discussion}

The top models in our analysis indicated that the average monthly rainfall was significantly higher prior to outbreaks when allowing for time lags of 12 to 23 months (14 months in the best model). These findings support our initial hypothesis and suggest that an increased risk of AIV outbreaks in poultry exists after (1) a period of intense rainfall over a period of four to 16 months (14 months in best model), presumably triggering increased waterbird breeding and increased numbers of immunologically naïve juvenile waterbirds, which (2) enter the population at gradually increasing densities over a time lag between 12 and 23 months (14 months in best model). The time lag between intense rainfalls and outbreaks in poultry are in agreement with Ferenczi et al.'s [18] findings from southeast Australia, where higher rainfall three to seven months before higher AIV prevalence in wild waterbird populations was observed. That the time lag is substantially longer in the present study than in Ferenczi et al. [18] probably relates primarily to the extra time needed for AIV to spillover from wild birds into poultry, which may importantly be facilitated by increased densities of ducks following a dry period (see below) and possibly, at least in half of the cases, the time needed for the LPAI to evolve in a HPAI.

A dominant feature of Australian climate is the ENSO-linked irregularity in both timing and location of wet and dry periods $[37,57,58]$. These erratic climate patterns may relax seasonality in waterfowl breeding, where reproduction occurs after periods of higher rainfall and associated increases in food availability [28, 29, 34]. Ferenczi et al. [18] indicated that after rainfalltriggered breeding events, the influx of juveniles that arrive from inland areas that mix with locally hatched juveniles, were likely drivers of AIV prevalence dynamics in two wild duck species on a coastal permanent 
Table 1 High pathogenicity (HPAl) and low pathogenicity (LPAI) avian influenza virus outbreaks in commercial poultry across the Murray-Darling basin and close vicinity between 1976 and 2020

\begin{tabular}{|c|c|c|c|c|c|c|}
\hline Year & Month & State & Location & Affected stock & $\begin{array}{l}\text { HPAI / LPAI } \\
\text { subtype }\end{array}$ & Reference \\
\hline 1976 & January & Victoria & $\begin{array}{l}\text { Keysborough } \\
\text { (outer suburbs of Melbourne) }\end{array}$ & chicken, duck & HPAI, H7N7 & {$[45]$} \\
\hline 1985 & May & Victoria & Bendigo & chicken & HPAI, H7N7 & {$[45]$} \\
\hline 1992 & July & Victoria & West Victoria & duck & LPAI, H3N8 & [51] \\
\hline 1992 & July & Victoria & Bendigo & chicken, duck & HPAl, H7N3 & {$[45,49]$} \\
\hline 1994 & December & Queensland & Lowood & chicken & HPAl, H7N3 & {$[45]$} \\
\hline 1997 & November & $\begin{array}{l}\text { New South } \\
\text { Wales }\end{array}$ & Tamworth & $\begin{array}{l}\text { chicken, } \\
\text { emu }\end{array}$ & $\mathrm{HPAl}, \mathrm{H} 7 \mathrm{~N} 4$ & {$[45,50]$} \\
\hline 2006 & October & $\begin{array}{l}\text { New South } \\
\text { Wales }\end{array}$ & Sydney Basin & chicken, duck & LPAl, H6N4 & {$[45]$} \\
\hline 2010 & March & $\begin{array}{l}\text { New South } \\
\text { Wales }\end{array}$ & Sydney basin & chicken & LPAI, H10N7 & {$[46]$} \\
\hline 2012 & January & Victoria & Melbourne & duck & LPAl, H5N3 & {$[47,48]$} \\
\hline 2012 & April & $\begin{array}{l}\text { New South } \\
\text { Wales }\end{array}$ & Hunter Valley & turkey & LPAl, H9N2 & {$[46]$} \\
\hline 2012 & April & $\begin{array}{l}\text { New South } \\
\text { Wales }\end{array}$ & North Coast & duck & LPAl, H4N6 & {$[46]$} \\
\hline 2012 & November & $\begin{array}{l}\text { New South } \\
\text { Wales }\end{array}$ & Hunter Valley & chicken & HPAl, H7N7 & {$[46]$} \\
\hline 2013 & October & $\begin{array}{l}\text { New South } \\
\text { Wales }\end{array}$ & Young & chicken & $\mathrm{HPAl}, \mathrm{H} 7 \mathrm{~N} 2$ & {$[48]$} \\
\hline 2020 & July & Victoria & Lethbridge & chicken & HPAl, H7N7 & [48] \\
\hline 2020 & August & Victoria & Lethbridge & turkey & LPAl, H5N2 & {$[48]$} \\
\hline 2020 & August & Victoria & Kerang & emu & LPAl, H7N6 & [48] \\
\hline
\end{tabular}

wetland. Thus the time lag that is observed between breeding and the increased AIV prevalence in waterfowl populations after breeding [18] is likely reflected in AIV outbreaks in poultry.

The delay between a high rainfall period and the occurrence of AIV outbreaks in poultry is consistent with the earlier hypothesised idea that the likelihood of AIV outbreaks in poultry increases as temporary wetlands dry up [39]. As inland wetland systems contract with the onset of dry periods, associated wild waterbirds from these regions [34, 35] may concentrate on a few remaining waterbodies, such as farm dams. In these situations, they may be in direct or indirect contact with poultry, which increases the likelihood of virus transmission between wild and domestic birds.

Recognizing the role of rainfall as a major driver of waterbird population dynamics, Vijaykrishna et al. [59] showed a decrease in AIV diversity during years when the rainfall across Australia was below average. To our knowledge, Vijaykrishna et al.'s [59] rainfall driven evolutionary dynamics of AIV and Ferenczi et al.'s [18] rainfall driven viral prevalence in waterfowl are the only studies that address the idea that non-seasonal rainfall patterns are a major driver of AIV dynamics in this part of the world. Although rainfall is considered to be of less importance in AIV dynamics in the northern hemisphere, a few studies have found it to influence AIV prevalence in wild and domestic birds [60, 61]. East et al.'s [62] study of H5N1 HPAI infection risk analysis in Australia suggested that the areas of highest risk for introduction of AIV from wild birds into poultry were in eastern Australia where there are (1) higher densities of poultry farms; (2) more wetland habitats for waterbirds and (3) the climate is wetter [62].

Our study, albeit drawing conclusions based on correlations exclusively, highlights the importance of investigating AIV dynamics in both wild and domestic birds in relation to different environmental and ecological factors, allowing for a better understanding of AIV transmission risks between them. Additionally, and notably for systems regularly experiencing extreme weather events, such studies may allow for an improved understanding of the climatic drivers of disease dynamics. Climatic forcing of disease dynamics is commonly assumed for both humans and wildlife [17, 24, 63]. However, the evaluation of causality between weather conditions and disease patterns is often hampered by high levels of seasonality, which notably prevail in the northern 


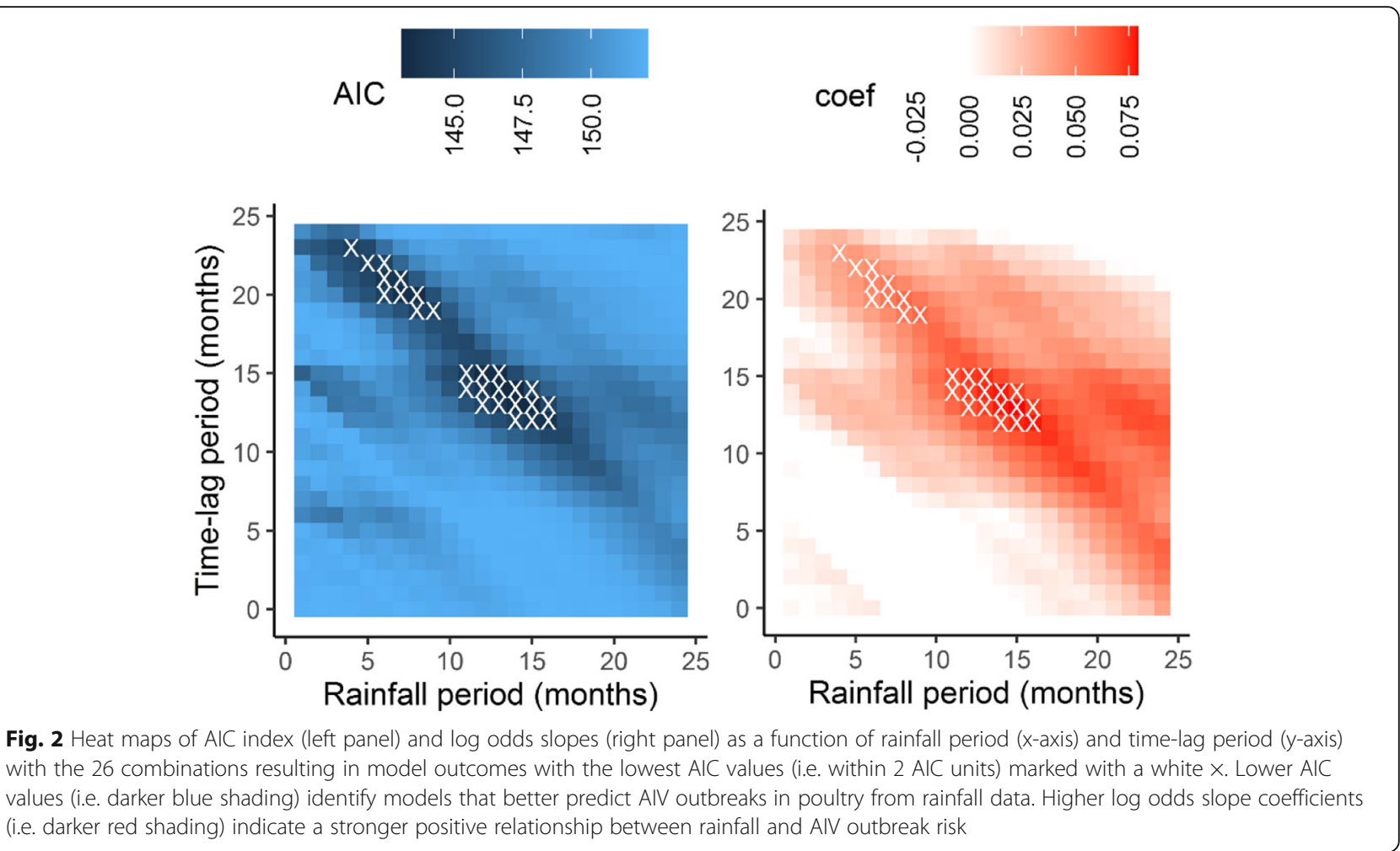

hemisphere. Disease-dynamics studies in regions of the world with less predictable climatic conditions, such as in large parts of Australia and many other areas of the southern hemisphere, may thus provide important insights in the true drivers of disease dynamics and the consequences of climate change on disease dynamics $[47,64]$.

\section{Supplementary information}

The online version contains supplementary material available at https://doi. org/10.1186/s12917-021-03010-9.

\section{Additional file 1}

\section{Acknowledgements}

We received much appreciated help in data collection from Tiggy Grillo, Nina Kung and Paul Selleck. We thank Bill Buttemer, Andrew Breed, Tiggy Grillo and two anonymous reviewers for their constructive comments on the manuscript.

\section{Authors' contributions}

Marta Ferenczi, Christa Beckmann and Marcel Klaassen participated in designing the study. Marta Ferenczi collected the data. Marta Ferenczi and Marcel Klaassen conducted the data analysis. Marta Ferenczi wrote the first draft. Christa Beckmann and Marcel Klaassen participated in the interpretation of results and provided feedback on the manuscript. All authors read and approved the final manuscript.

\section{Funding}

Not applicable.
Availability of data and materials

The data that support the findings of this study are available from the Australian Bureau of Meteorology (http://www.bom.gov.au/climate/change/ index.shtml\#tabs=Tracker\&tracker=timeseries); NSW Animal Health Surveillance Newsletters (https://www.dpi.nsw.gov.au/about-us/publications/ animal-health-surveillance); Animal Health in Australia Annual Reports (www. animalhealthaustralia.com.au); and World Animal Health Information Database (WAHID) Interface (www.oie.int/wahis_2/public/wahid.php/ Wahidhome/Home). Additional file 1 is provided as an Rmarkdown html file, containing the R script and detailed output of the calculations.

\section{Declarations}

Ethics approval and consent to participate Not applicable.

\section{Consent for publication}

Not applicable.

\section{Competing interest}

The authors declare that they have no competing interests.

\section{Author details}

${ }^{1}$ Centre for Integrative Ecology, School of Life \& Environmental Sciences, Deakin University, 75 Pigdons Road, 3216 Geelong, VIC, Australia. ${ }^{2}$ School of Science, Western Sydney University, Locked Bag 1797, 2751 Penrith, NSW, Australia. ${ }^{3}$ Hawkesbury Institute for the Environment, Western Sydney University, Locked Bag 1797, 2751 Penrith, NSW, Australia.

Received: 6 January 2021 Accepted: 1 September 2021

Published online: 14 September 2021

\section{References}

1. Gilbert M, Pfeiffer DU: Risk factor modelling of the spatio-temporal patterns of highly pathogenic avian influenza (HPAIV) H5N1: a review. Spatial and spatio-temporal epidemiology 2012, 3(3):173-183. 
2. Gilbert M, Golding N, Zhou H, Wint GW, Robinson TP, Tatem AJ, Lai S, Zhou S, Jiang H, Guo D: Predicting the risk of avian influenza A H7N9 infection in live-poultry markets across Asia. Nature communications 2014, 5:4116.

3. Vergne T, Paul MC, Chaengprachak W, Durand B, Gilbert M, Dufour B, Roger F, Kasemsuwan S, Grosbois V: Zero-inflated models for identifying disease risk factors when case detection is imperfect: application to highly pathogenic avian influenza $\mathrm{H} 5 \mathrm{~N} 1$ in Thailand. Preventive veterinary medicine 2014, 114(1):28-36

4. Alexander DJ: A review of avian influenza in different bird species. Veterinary microbiology 2000, 74(1-2):3-13.

5. Lycett SJ, Bodewes R, Pohlmann A, Banks J, Bányai K, Boni MF, Bouwstra R, Breed AC, Brown $\mathrm{H}$, Chen $\mathrm{H}$ : Role for migratory wild birds in the global spread of avian influenza H5N8. 2016.

6. Verhagen JH, Fouchier RAM, Lewis N: Highly Pathogenic Avian Influenza Viruses at the Wild-Domestic Bird Interface in Europe: Future Directions for Research and Surveillance. Viruses 2021, 13(2):212.

7. Capua I, Alexander DJ: Avian influenza and human health. Acta tropica 2002 83(1):1-6.

8. Ellis TM, Barry Bousfield R, Bissett LA, Dyrting KC, Luk GS, Tsim S, SturmRamirez K, Webster RG, Guan Y, Peiris JM: Investigation of outbreaks of highly pathogenic $\mathrm{H} 5 \mathrm{~N} 1$ avian influenza in waterfowl and wild birds in Hong Kong in late 2002. Avian Pathology 2004, 33(5):492-505.

9. Kuiken T, Harder T: H5N1 Highly pathogenic avian influenza: breaking rules in disease emergence. In: New Directions in Conservation Medicine: Applied Cases of Ecological Health. edn. New York: Oxford University Press; 2012.

10. Morgan I, Kelly A: Epidemiology of an avian influenza outbreak in Victoria in 1985. Australian Veterinary Journal 1990, 67(4):125-128.

11. Burns TE, Ribble C, Stephen C, Kelton D, Toews L, Osterhold J, Wheeler H: Use of observed wild bird activity on poultry farms and a literature review to target species as high priority for avian influenza testing in 2 regions of Canada. The Canadian Veterinary Journal 2012, 53(2):158.

12. Bouwstra R, Gonzales JL, de Wit S, Stahl J, Fouchier RA, Elbers AR: Risk for Low Pathogenicity Avian Influenza Virus on Poultry Farms, the Netherlands, 2007-2013. Emerging infectious diseases 2017, 23(9):1510.

13. Olsen B, Munster VJ, Wallensten A, Waldenström J, Osterhaus ADME, Fouchier RAM: Global patterns of influenza A virus in wild birds. Science 2006, 312:384-388.

14. van Dijk JGB, Verhagen JH, Wille M, Waldenström J: Host and virus ecology as determinants of influenza A virus transmission in wild birds. Curr Opin Virol 2018, 28:26-36.

15. Munster VJ, Baas $C$, Lexmond $P$, Waldenström J, Wallensten A, Fransson $T$, Rimmelzwaan GF, Beyer WE, Schutten M, Olsen B: Spatial, temporal, and species variation in prevalence of influenza $A$ viruses in wild migratory birds. PLoS pathogens 2007, 3(5):e61.

16. Dijk JG, Hoye BJ, Verhagen JH, Nolet BA, Fouchier RA, Klaassen M: Juveniles and migrants as drivers for seasonal epizootics of avian influenza virus. Journal of Animal Ecology 2014, 83(1):266-275.

17. Lisovski S, Hoye BJ, Klaassen M: Geographic variation in seasonality and its influence on the dynamics of an infectious disease. Oikos 2017, 126(7):931-936.

18. Ferenczi M, Beckmann C, Warner S, Loyn R, O'riley K, Wang X, Klaassen M: Avian influenza infection dynamics under variable climatic conditions, viral prevalence is rainfall driven in waterfowl from temperate, south-east Australia. Veterinary research 2016, 47(1):23.

19. Gaidet N, Caron A, Cappelle J, Cumming GS, Balança G, Hammoumi S, Cattoli G, Abolnik C, de Almeida RS, Gil P: Understanding the ecological drivers of avian influenza virus infection in wildfowl: a continental-scale study across Africa. Proc R Soc B 2011:rspb20111417.

20. Ferenczi M: A description of the avian influenza reservoir community in wild Australian birds and the role of phylogeny, ecology and ecoregion. In: A description of the avian influenza reservoir community in wild Australian birds and the role of phylogeny, ecology and eco-region. edn. PhD thesis: Deakin University; 2016: 24-56.

21. Altizer $S$, Bartel $R$, Han BA: Animal migration and infectious disease risk. science 2011, 331(6015):296-302.

22. Hinshaw V, Bean W, Webster R, Sriram G: Genetic reassortment of influenza A viruses in the intestinal tract of ducks. Virology 1980, 102(2):412-419.

23. Risely A, Klaassen M, Hoye BJ: Migratory animals feel the cost of getting sick: A meta-analysis across species. Journal of Animal Ecology 2018, 87(1):301314.

24. Hosseini PR, Dhondt AA, Dobson A: Seasonality and wildlife disease: how seasonal birth, aggregation and variation in immunity affect the dynamics of Mycoplasma gallisepticum in house finches. Proceedings of the Royal Society of London B: Biological Sciences 2004, 271(1557):2569-2577.

25. Loyn R, Rogers D, Swindley R, Stamation K, Macak P, Menkhorst P: Waterbird Monitoring at the Western Treatment Plant, 2000-12: The Effect of Climate and Sewage Treatment Processes on Waterbird Populations: Arthur Rylah Institute for Environmental Research, Department of Environment and Primary Industries; 2014.

26. Chown SL, Sinclair BJ, Leinaas HP, Gaston KJ: Hemispheric asymmetries in biodiversity—a serious matter for ecology. PLoS biology 2004, 2(11):e406

27. Woodall PF: Waterbird populations in the Brisbane region, 1972-83, and correlates with rainfall and water heights. Wildlife Research 1985, 12(3):495506.

28. Halse S, Jaensch R: Breeding seasons of waterbirds in South-western Australia - the importance of rainfall. Emu 1989, 89(4):232-249.

29. Marchant S, Higgins P: Handbook of Australian, New Zealand and Antarctic birds. Volume 1: Ratites to ducks. In.: Oxford University Press, Melbourne; 1990.

30. Ummenhofer CC, England MH, McIntosh PC, Meyers GA, Pook MJ, Risbey JS, Gupta AS, Taschetto AS: What causes southeast Australia's worst droughts?Geophysical Research Letters 2009, 36(4).

31. Norman F, Nicholls N: The Southern Oscillation and variations in waterfowl abundance in southeastern Australia. Austral Ecology 1991, 16(4):485-490.

32. Gergis J, Gallant AJE, Braganza K, Karoly DJ, Allen K, Cullen L, D'Arrigo R, Goodwin I, Grierson P, McGregor S: On the long-term context of the 19972009 'Big Dry'in South-Eastern Australia: insights from a 206-year multi-proxy rainfall reconstruction. Climatic Change 2012, 111(3-4):923-944.

33. Bethke RW, Nudds TD: Effects of Climate Change and Land Use on Duck Abundance in Canadian Prairie-Parklands. Ecological Applications 1995, 5(3): 588-600.

34. Briggs S: Movement patterns and breeding characteristics of arid zone ducks. Corella 1992, 16(10):15-22.

35. Roshier D, Whetton P, Allan R, Robertson A: Distribution and persistence of temporary wetland habitats in arid Australia in relation to climate. Austral Ecology 2001, 26(4):371-384.

36. Briggs S, Maher M: Limnological studies of waterfowl habitat in southwestern New South Wales. II. Aquatic macrophyte productivity. Marine and Freshwater Research 1985, 36(5):707-715.

37. Kingsford R, Norman F: Australian waterbirds - products of the continent's ecology. Emu 2002, 102(1):47-69.

38. Roshier D, Robertson A, Kingsford R: Responses of waterbirds to flooding in an arid region of Australia and implications for conservation. Biological conservation 2002, 106(3):399-411.

39. Klaassen M, Hoye BJ, Roshier DA: Identifying crucial gaps in our knowledge of the life-history of avian influenza viruses-an Australian perspective. Emu 2011, 111(2):103-112.

40. Appleby B, Anwar M, Petty S: Short-term and long-term effects of food supply on parasite burdens in Tawny Owls, Strix aluco. Functional Ecology 1999, 13(3):315-321.

41. Keawcharoen J, Van Riel D, van Amerongen G, Bestebroer T, Beyer WE, Van Lavieren R, Osterhaus AD, Fouchier RA, Kuiken T: Wild ducks as longdistance vectors of highly pathogenic avian influenza virus (H5N1). Emerging infectious diseases 2008, 14(4):600.

42. Kim JK, Negovetich NJ, Forrest HL, Webster RG: Ducks: the "Trojan horses" of H5N1 influenza. Influenza and other respiratory viruses 2009, 3(4):121-128.

43. Tian H, Zhou S, Dong L, Van Boeckel TP, Cui Y, Newman SH, Takekawa JY, Prosser DJ, Xiao X, Wu Y: Avian influenza H5N1 viral and bird migration networks in Asia. Proceedings of the National Academy of Sciences 2015, 112(1):172-177.

44. Scott A, Hernandez-Jover M, Groves P, Toribio JA: An overview of avian influenza in the context of the Australian commercial poultry industry. One Health-Amsterdam 2020, 10.

45. Australia. Department of Agriculture F, Forestry: National Avian Influenza Surveillance Dossier: Department of Agriculture, Fisheries and Forestry; 2010.

46. https://wwwdpi.nswgov.auabout-us/publications/animal-health-surveillance. Accessed 1 Dec 2015. https://www.dpi.nsw.gov.au/about-us/publications/a nimal-health-surveillance.

47. Australia AH: Animal health in Australia 2012. In. Canberra, Australia; 2013.

48. https://wahis.oie.int/.

49. Forsyth W, Grix D, Gibson C: Diagnosis of highly pathogenic avian influenza in chickens: Bendigo 1992. Australian Veterinary Journal 1993, 70(3):118-119.

50. Selleck P, Arzey G, Kirkland P, Reece R, Gould A, Daniels P, Westbury H: An outbreak of highly pathogenic avian influenza in Australia in 1997 caused by an H7N4 virus. Avian diseases 2003, 47(s3):806-811. 
51. Selleck PW, Hooper PT, Grix DC, Morrow CJ. The characterization of an Influenza-A virus isolated from Victorian ducks. Aust Vet J. 1994;71(7):222-3.

52. Scott A, Hernandez-Jover M, Groves P, Toribio J-A: An overview of avian influenza in the context of the Australian commercial poultry industry. One Health 2020, 10:100139.

53. Scott A: Relationships between waterbird ecology and river flows in the Murray-Darling Basin. In: Technical Report. vol. 5/97: CSIRO Land and Water; 1997: 46.

54. http://www.bom.gov.au/climate/change/index.shtml\#tabs=Tracker\&tracker= timeseries.

55. Letnic M, Dickman CR: Boom means bust: interactions between the El Niño/ Southern Oscillation (ENSO), rainfall and the processes threatening mammal species in arid Australia. Biodiversity \& Conservation 2006, 15(12):3847-3880.

56. RDevelopment CORE TEAM R: R: A language and environment for statistical computing. In.: R foundation for statistical computing Vienna, Austria; 2008.

57. Kousky VE, Kagano MT, Cavalcanti IF: A review of the Southern Oscillation: oceanic-atmospheric circulation changes and related rainfall anomalies. Tellus A 1984, 36(5):490-504.

58. Kingsford R, Roshier D, Porter J: Australian waterbirds-time and space travellers in dynamic desert landscapes. Marine and Freshwater Research 2010, 61(8):875-884.

59. Vijaykrishna D, Deng Y-M, Su YC, Fourment M, lannello P, Arzey GG, Hansbro PM, Arzey KE, Kirkland PD, Warner S: The recent establishment of North American $\mathrm{H} 10$ lineage influenza viruses in Australian wild waterfowl and the evolution of Australian avian influenza viruses. Journal of virology 2013, 87(18):10182-10189.

60. Si Y, de Boer WF, Gong P: Different environmental drivers of highly pathogenic avian influenza $\mathrm{H} 5 \mathrm{~N} 1$ outbreaks in poultry and wild birds. PloS one 2013, 8(1):e53362.

61. Hu W, Zhang W, Huang X, Clements A, Mengersen K, Tong S: Weather variability and influenza A (H7N9) transmission in Shanghai, China: A Bayesian spatial analysis. Environmental research 2015, 136:405-412.

62. East IJ, Hamilton SA, Sharp LA, Garner MG: Identifying areas of Australia at risk for $\mathrm{H} 5 \mathrm{~N} 1$ avian influenza infection from exposure to nomadic waterfowl moving throughout the Australo-Papuan region. Geospatial Health 2008, 3(1):17-27.

63. Koelle K, Pascual M: Disentangling extrinsic from intrinsic factors in disease dynamics: a nonlinear time series approach with an application to cholera. The American Naturalist 2004, 163(6):901-913.

64. Gilbert M, Slingenbergh J, Xiao X: Climate change and avian influenza. Revue scientifique et technique (International Office of Epizootics) 2008, 27(2): 459.

\section{Publisher's Note}

Springer Nature remains neutral with regard to jurisdictional claims in published maps and institutional affiliations.

Ready to submit your research? Choose BMC and benefit from:

- fast, convenient online submission

- thorough peer review by experienced researchers in your field

- rapid publication on acceptance

- support for research data, including large and complex data types

- gold Open Access which fosters wider collaboration and increased citations

- maximum visibility for your research: over $100 \mathrm{M}$ website views per year

At $\mathrm{BMC}$, research is always in progress.

Learn more biomedcentral.com/submissions 